Max-Planck-Institut für demografische Forschung

Max Planck Institute for Demographic Research

Doberaner Strasse 114 - D-18057 Rostock - GERMANY

Tel +49 (0) 3812081 - 0; Fax +49 (0) 3812081 - 202;

http://www.demogr.mpg.de

MPIDR WORKING PAPER WP 2001-027

AUGUST 2001 (REVISED OCTOBER 2002)

\title{
Non-Marital Births \\ in East Germany after Unification
}

Dirk Konietzka (dirk.konietzka@wisofak.uni-rostock.de)

Michaela Kreyenfeld (kreyenfeld@ demogr.mpg.de)

This working paper has been approved for release by: Hans-Peter Kohler (kohler@ demogr.mpg.de)

Head of the Research Group on Social Dynamics and Fertility.

(C) Copyright is held by the authors.

Working papers of the Max Planck Institute for Demographic Research receive only limited review.

Views or opinions expressed in working papers are attributable to the authors and do not necessarily reflect those of the Institute. 


\section{Non-Marital Births in East Germany after Unification}

Dirk Konietzka* and Michaela Kreyenfeld**

\footnotetext{
* Institute for Sociology and Demography, University of Rostock

** Max Planck Institute for Demographic Research, Rostock
} 


\begin{abstract}
Contrary to West Germany, where marriage and childbirth has been strongly "coupled", the German Democratic Republic (GDR) displayed high rates of non-marital childbearing. Researchers attributed this pattern to "misguided" GDR family policies, which encouraged women to remain unmarried upon childbirth. With German unification the East German legal and political institutions --including GDR family policies-- were replaced with West German ones. Against this background, it was widely expected that East German non-marital birth rates would soon fall to West German levels. However, after unification, they increased even further. In this paper, we argue that the enormous East-West differences in non-marital childbearing in the 1990s can be attributed to differences in women's work orientation. Despite unfavorable labor market constraints and social policies that foster women's withdrawal from the labor market after childbirth, East German women are still more likely to be employed fulltime, and they return to the labor market sooner after childbirth than their West German counterparts. Our empirical investigation which draws on data from the German microcensus 1997 reveals a strong impact of women's education and employment on marriage in West Germany, whereas in East Germany the probability to live in a marital union is hardly correlated with women's employment characteristics. Our conclusion is that an overall high female work orientation and a wide availability of public day care are the most important factors that weaken the economic incentives for women to get married upon childbirth in East Germany.
\end{abstract}

Keywords: Cohabitation, Female Employment, Germany, Non-Marital Childbearing 


\section{Introduction}

In comparison to other European countries, West Germany displays relatively low rates of non-marital childbearing. Since the 1960s, there has been an increase in the age at first marriage, a postponement of first birth, and an increase in childlessness (Council of Europe, 2000; Dorbritz, 2000: 257). Nevertheless, childbirth and marriage remain strongly coupled, which has prompted researchers to speak of a child oriented marriage in West Germany (Nave-Herz, 1994: 9). In the former East Germany, non-marital childbearing was relatively high compared to other European countries --particularly compared to West Germany. Since the 1970s, non-marital birth rates have steadily increased, reaching 33 percent in 1989. Overwhelmingly, researchers attributed this development to GDR policies (Trappe, 1995: 210; Cromm, 1998). The intended aim of the government was to support single mothers, but the regulations may have also encouraged women not to get married. With the breakdown of communism and the replacement of East German institutions with West German ones, it seemed likely that East Germans would adapt western demographic patterns; i.e., non-marital birth rates would soon fall to West German levels (Höhn and Dorbritz, 1995: 171; Witte and Wagner, 1995: 395). Surprisingly, after unification non-marital birth rates sky-rocketed, exceeding 50 percent in the year 2000 (see Figure1).

[Figure 1 about here]

The steady increase in non-marital birth rates in East Germany after unification poses several unresolved questions. In this paper, our focus is on the role of family policies and women's employment, which may explain the unexpected development of out-ofwedlock childbearing. With respect to family policies, the crucial question is why nonmarital births increased when the incentive structure in contemporary Germany is designed to strongly support marital childbearing (Huinink, 1998: 301)? Is this an irrational response of East German women or couples to the new family polices? Do East Germans use the new incentive structure strategically, while West Germans have failed to do so for decades? Or are East Germans simply turning their backs on 
“traditional family forms"? Another question closely related to this issue: Do women's employment, economic independence and work orientation weaken the role of marriage as an institution for raising children?

In order to investigate this issue, it is necessary to distinguish among different "types" of non-marital births. Taking into account the modernization of family forms and new living arrangements like cohabiting unions (e.g. Seltzer, 2000; Smock, 2000; Raley, 2001), we can distinguish among births to single mothers, births in marital unions and births in cohabiting unions. Furthermore, from a longitudinal perspective, the cohabiting couple may get married shortly after the birth of their first (or second) child or remain unmarried permanently. Researchers initially classified cohabiting unions as "trial marriages" (e.g. Bennett et al., 1988), but they now acknowledge that, to some extent, cohabiting couples represent independent and permanent family forms. In this study, our primary focus is on women who permanently live in cohabiting unions with children.

The remainder of this paper is structured as follows. In Part 1, we give an overview of family policies that defined relevant conditions of non-marital childbearing in East Germany before and after unification. In this context, we sketch our main hypothesis that non-marital parenthood can be related to a high work orientation among East German women. Part 2 contains the description of the data and the procedure of the analysis. In Part 3, we investigate how a woman and her male partner's employment characteristics relate to marriage decisions in East and West Germany. Part 4 contains the concluding discussion.

\section{Family Policies and Non-Marital Births in East and West Germany}

\section{Family Policies before Unification}

In the GDR, family policies were openly pro-natalistic and contained various regulations that supported an early marriage. Upon marriage, couples received a "home 
furnishing loan" of 7,000 Marks (5,000 Marks until 1986) and priority access to a flat for themselves. However, there were also several important regulations that fostered single parenthood. Children of single mothers received priority access to public day care. When a child was sick or when day care could not be provided, she was guaranteed paid leave (Gysi and Speigner, 1983; Obertreis 1986). The most important policy measure, however, was the Babyjahr which was introduced in 1976: After the birth of a child, a single mother was allowed to take a year of paid leave. ${ }^{1}$ Married mothers, on the other hand, were only allowed to take advantage of this regulation after the birth of a second or higher order child. Since married and non-married couples were treated alike once the second child was born, the birth of the second child often was an opportunity to get married (Huinink and Wagner, 1995; Huinink, 1999: 127).

The Babyjahr was regarded as the main reason for the rapid increase in non-marital births (to roughly 30 percent in the 1980s) (Höhn, 1992: 9). Changes in the housing "market" were presumably another important factor supporting this development. In the 1970s, marriage was still a major tool to get access to a flat in the strongly regulated East German housing "market", but by the 1980s, the housing shortage was partially relieved and it become easier for unmarried couples to be allocated an apartment by the local authorities.

The increase in non-marital birth rates was largely considered a very unintended effect of East German family policies (Trappe, 1995: 210). In 1986, the GDR government responded to the changes in childbearing patterns by allowing married women to take a year of paid leave after the birth of the first child. The extension of the Babyjahr put a halt to a further increase of non-marital births; however, until the breakdown of the GDR, there was no sizeable decline in non-marital birth rates (see Figure 1).

1 Since 1961, women have been allowed to take one year of unpaid leave after childbirth. Since 1976, mothers with two and more children have been entitled to a year of paid leave (which amounts to the usual sick pay that was granted after the 7th week of sickness). Since 1984, mothers with more than two children have been entitled to 18 months of paid leave. In 1986, paid leave was extended to all mothers. If no slot in day care could be found, all mothers were entitled to extend their period of unpaid leave up to the third birthday of the child (Frerich and Frey, 1993; Cromm,1998). 


\section{Family Policies after Unification}

In October 1990, the two German states were united and the East German legal and political system was basically replaced by the West German one. ${ }^{2}$ Single mothers in the FRG are, as it was the case in the former East Germany, subject to special treatments. They are still entitled to take paid leave when a child is sick, and single parenthood is a key characteristic that makes it more likely to receive a slot in a public day care institution (Dorbritz, 1997: 243). ${ }^{3}$ Furthermore, there are several means tested transfer payments (such as maternity leave, social welfare, and housing benefits). Single parents who are not working have priority access to these treatments since they do not live with a partner whose income is assessed.

Although one should bear these regulations in mind for the subsequent analysis, it is unlikely that they are able to explain the huge East-West differences in marital patterns. The most important reason for this is that, in contrast to the GDR, most regulations in present-day Germany make an explicit distinction among cohabiting unions (Nichteheliche Lebensgemeinschaft), marital unions and singles (Peuckert, 1999; Schneider and Matthias-Bleck, 1999). Child-rearing benefits, social welfare and housing benefits are means tested and the income of the non-married partner (as long as he is cohabiting) is taken into account, too. A similar assessment applies to priority access to children's day care. While single motherhood entitles one to priority access to a day care slot, children of couples in cohabiting and marital unions are usually be treated alike. Since the majority of non-married East German women with children are living in cohabiting unions (see below), they are not be able to take advantage of these regulations. Finally, social welfare and housing benefits are only of interest for couples who earn a very low labor market income and/or are subject to bleak employment

At German unification, the Unification Treaty (Einigungsvertrag) went into force, which prescribed that East German institutions to be replaced by West German ones. However, it should be noted that some East German regulations were only gradually abolished. Paid leave when a child was sick was still valid until July 1991. Parental leave regulations and child benefits were changed in January 1991 (Berghahn, 1992: 78ff.; Frerich and Frey, 1996).

3 Since 1992, married women (and in principle also married men) are entitled to take 10 days of paid leave to care for the sick child (20 for parents with more than one child). Single parents can take 25 days of paid leave to care for the sick child (50 days for single parents with more than one child) (BMA, 2000: 152f.). 
prospects. Despite relatively unfavorable labor market conditions, only a minority of East German men are permanently out of work (Brinkmann and Wiedemann, 1995: 330; Mayer et al., 1999). In summary, the German tax and transfer system sets some incentives for non-working single mothers to avoid moving in with their partners. However, it does not discourage cohabiting couples from getting married.

On the contrary, there are several important transfer payments which strongly favor marriage. This pertains to the system of income splitting which allows married couples to file their taxes jointly. This means that the man and the woman's income are added together, divided by two and taxed as individual incomes. Due to progressive taxation in Germany, this regulation results in high tax relief for couples in which the man and the woman earn very unequal wages. Put another way, this measure encourages couples to get married, particularly when one of the partners is permanently not employed (or employed part-time) and the other partner is working full-time. The German health care and pension system contains similar regulations. Married housewives (and in principle "housemen") are covered by the statutory health insurance of the spouse and entitled to a widow's (or widower's) pension.

In sum, the German institutional framework strongly encourages couples to get married, particularly when one of the partners withdraws from full-time employment after childbirth (e.g. Sainsbury, 1997; Drobnič, 2000). These regulations are, however, less decisive for East German women, since they are substantially more likely to be employed full-time. In the following, we discuss this issue in greater detail.

\section{Female Employment in East and West Germany}

Especially in the early 1990s, East German women were subject to very unfavorable labor market constraints, i.e. high female unemployment rates, low re-employment rates and high risks of downward status mobility once unemployed (Mayer, et al.1999; Beckmann and Engelbrech, 1999: 206). Some researchers speculated that most East German women would soon be discouraged from their labor market opportunities and, similar to their West German counterparts, inclined to follow the traditional "malebreadwinner model" once they had a child (Dorbritz 1997: 243; Huinink 1999: 129). 
Although macroeconomic conditions remained less advantageous throughout the 1990s, full-time employment rates among East German women stayed well above West German levels. Various empirical studies show that East German women taking parental leave return to the labor market more quickly than their West German counterparts; and those who are currently unemployed are looking for employment more actively and are more certain that they want to return to the labor market. Furthermore, East German women who are employed part-time often prefer to extend their work hours (Engelbrech 1997; Holst and Schupp 1999).

East-West differences in employment patterns are particularly pronounced for women with children. Figure 2 displays the employment rates of mothers by the age of their first children. The figure clearly shows that East German women with children are more likely to be employed full-time than females in West Germany. When the first child reaches primary school age (i.e. age 6), only 10 percent of West German mothers are employed full-time, 29 percent work part-time and 59 percent are unemployed. In the East, the pattern is almost reversed. When the first child reaches primary school age, 36 percent of all mothers are employed full-time; only 38 percent are not employed.

[Figure 2 about here]

How can we explain the East-West differences in mothers' employment patterns? The pervasive stance on this issue is presumably that East German women have a higher work orientation than their more traditional counterparts in the West. As a holdover from former socialist times, they consider economic independence and a full-time employment career as a "matter of course" (Braun et al. 1994; Adler, 1997). Although there is little to dispute about the striking East-West differences in women's work orientation, one does have to relate them to the differences in the constraints for women's participation in the labor market. One important issue, for example, is that also the labor market situation of East German males has remained relatively unfavorable, possibly putting East German women under greater financial pressures to participate in the labor market. From this perspective, high female employment rates do 
not primarily reflect women's striving for economic independence but the necessity of both partners in contributing to a joint household income. Furthermore, East German women are subject to a relatively favorable situation in combining childrearing and employment. Contrary to a widespread belief that unification would be followed by an immediate closure of public day care centers (e.g. Adler, 1997: 44; Rindfuss and Brewster, 1996: 273), there was a relatively broad coverage of public day care in the East throughout the 1990s. In 1998, the provision rate of public day care for children ages 0 to 3 was only 3 percent in the West, but 36 percent in the East. There is complete coverage with full-time care for pre-school children (ages 4-6) in the Eastern states, but only coverage of 19 percent in the Western states (see Table 1). ${ }^{4}$

[Table 1 about here]

Ultimately, it is hard to tell whether high employment rates among East German women are part of a general attitude that full-time employment is simply a "matter of course," or whether women with children are pulled into the labor market due to financial pressures. It is also difficult to know whether East German mothers are employed in higher numbers because conditions are more favorable to combine childrearing and employment, or whether work-oriented women put East German communities under greater pressure to provide day care slots. Whatever the reason, a high work orientation and more favorable conditions to participate in the labor market should have important implications for the decision to get married upon childbirth.

As discussed above, the German tax and transfer system is particularly beneficial for married couples who follow a gender-specific division of labor: i.e. one of the partners devotes most of her or his time to childrearing tasks while the other one is employed

4 One of the main reasons for the still broad coverage of public day care is most likely the low birth rates after unification which ultimately reduced the demand for care. In other words, day care slots were cut after unification, but since the number of children to care for declined even faster, the provision rates could be kept at a high level (see also Table 1, for a more thorough discussion of this issue, see Kreyenfeld, 2001). 
full-time. If, however, both partners are employed full-time, there are few economic benefits from marriage. Therefore, it seems reasonable to assume that East-West differences in non-marital childbearing primarily relate to East-West differences in the employment behavior of women. In short, we expect that differences in the work orientation among East and West German mothers are able to explain the divergent patterns in non-marital childbearing. In the following section, we investigate this hypothesis.

\section{Data Source \& Procedure of the Analysis}

\section{Data Source}

Our empirical analysis is based on data from the German micro-census of the year 1997 (hereafter referred to as "Mikrozensus"). The Mikrozensus is a sample of 1 percent of the population residing in Germany. In Western Germany, it has been conducted annually since the year 1957 (except for the years 1975, 1983 and 1984). In Eastern Germany, the first survey was conducted in 1991 (for details, see Emmerling and Riede, 1997; Schimpl-Neimanns, 1998). It covers standard demographic characteristics (such as age, nationality, and region of residence), employment status, educational attainment, etc. The major advantage of the Mikrozensus is its large sample size. This makes the Mikrozensus particularly suitable for the analysis of nuptiality and fertility patterns in East and West Germany after unification. Most other data sets either do not provide a sufficiently large sample size or cover too short of a time period. For example, the German Family and Fertility Survey (FFS) was conducted only during the spring of 1992, which means that it encompasses a very small "post unification period." Other recently available data sets such as the German Socio-Economic Panel (SOEP) and the Familiensurvey provide demographic information up to the year 2000. However, they contain too few cases, which does not allow for a separate analysis of "non marital births" in East and West Germany after unification (see Huinink and Konietzka, 2002).

Although the Mikrozensus 1997 provides a sufficiently large sample size and covers a relatively long time period after unification, there is one major drawback involved with 
using it to analyze demographic events. The Mikrozensus is a cross-sectional data set that provides little retrospective information. This particularly applies to the "fertility history" of the respondents. However, it is possible to reconstruct a woman's "fertility history" from the number of children who lived in the household at the time of the survey. Because this strategy involves a variety of problems - i.e. the older the woman the more likely it is that her children have already moved out of the parental home - we restricted our analysis to females born between 1961-1980; i.e. respondents who were between the ages of 17 and 36 at the time of the interview. ${ }^{5}$ Assuming that few women give birth before the age of 19 , children of these cohorts were at a maximum age of 18 at the time of interview. We only included persons who lived in private households and we omitted all cases where a birth occurred before age 17 .

\section{Procedure of the Analysis}

The primary focus of the subsequent analysis is the extent to which women's employment affects non-marital childbearing in East and West Germany. However, before proceeding with the main analysis, we first need to clarify our research strategy. This involves making a distinction between single, married and cohabiting women, as well as viewing marriage from a longitudinal perspective and relating it to fertility decisions. All in all, our empirical analysis consists of the following three steps:

(1) First, we investigate how marriage and first birth are "coupled". In this section, we explain why we focus on women with children aged 3 to 6 and why we restrict the analysis to women in marital and cohabiting unions -- i.e., why we omit single parents from the analysis.

(2) Secondly, we investigate the hypothesis that high non-marital birth rates reflect a high work orientation among East German women. In this section, we use several logistic regression models to estimate the probability of living in a marital union versus a cohabiting union. The key independent variables are the employment status

5 According to calculations on the basis of the Familiensurvey 2000, less than 5 percent of the children of women aged 31-35 have left the parental home. Less than 1 percent of their children were adopted or step-children (Kreyenfeld and Huinink, 2002). 
and the educational attainment of the woman and her partner. Furthermore, we make a distinction between relative and absolute educational attainment. By "relative," we mean that we compare the woman's educational attainment to that of her partner.

(3) Thirdly, we focus on East-West differences in non-marital childbearing. For this part of the analysis, we pool East and West Germans into one sample, however, interact various independent variables with the region of residence (i.e., East or West).

\section{Empirical Analysis}

\section{1. "Unmarried Parents": A Permanent Family Status?}

To what extent is non-marital parenthood a permanent living arrangement? The nonmarital birth rate provided by the German Statistical Office (see Figure 1) is a very crude indicator for marriage patterns since it classifies births as "non-marital" even though the couple might get married shortly after childbirth. It may be possible that West Germans try to avoid an "illegitimate" birth, while East Germans are less concerned about postponing marriage to the period shortly after the birth of the first child. Furthermore, non-marital birth rates mix births of different orders. One could argue that in East Germany non-marital birth rates for first births are high, but that couples get married at the birth of the second child. A possible rationale behind this is that two or more children are a serious impediment for the labor market career of a woman.

In order to address this issue empirically, we consider all women who had a first or second birth between 1991 and 1996. Using life table techniques, we show how 
marriage is concentrated around the birth of the first or second child. ${ }^{6}$ As can be seen from Figure 3, roughly 80 percent of the West German women are married at the end of the year they had their first child. In the East, this applies to roughly 45 percent. When the first child reaches one year of age, 51 percent of the East Germans and 84 percent of the West Germans are married. After three years, the picture looks almost the same: 58 percent of the East Germans and 86 percent of the West Germans are married. It follows from this that high non-marital birth rates in East Germany do not result from a postponement of marriage to the period shortly after first birth.

Figure 3 displays the survival curves by the age of the second child. Roughly 70 percent of the East German women and 90 percent of the West German women are married once the second child is born. Since second births rapidly declined after unification (Sackmann, 1999; Kreyenfeld, 2001), we can conclude that the high ratio of non-marital births is partially a composition effect.

[Figure 3 about here]

\section{Marital Union versus Cohabiting Union}

In the subsequent analysis, we investigate the extent to which women and their partner's employment characteristics influence marriage decisions. The survival curves (Figure 3) reveal that hardly any marriages occur after the first child reaches three years of age -i.e., marriage risks are high around the birth of the first child and rapidly level off thereafter. Against this background, we can consider as "immune" from marriage women who are still unmarried when the first child reaches three years of age. This assumption substantially simplifies the analysis. Most importantly, it allows us to change from the longitudinal to the cross-sectional perspective. In other words, we 
restrict the sample to women whose first child is at least three years of age and we consider the family status at the date of interview. ${ }^{7}$ Since children older than age 6 were already born (or at least conceived) during GDR-times, we also omit such cases from the analysis --i.e., we restrict the sample to mothers whose first children were between age 3 and 6 in $1997 .{ }^{8}$

Table 2 displays the descriptive statistics of the remaining sample (see also Appendix). As expected, there is a much lower percentage of cohabiting unions with children in West Germany. Most unmarried West German women with children (ages 3-6) are single mothers. In the East, the pattern is opposite. About 16 percent of all women with small children are single parents and 21 percent are living with a partner. East Germans tend to have their first child at a slightly younger age, but they are less likely to have a second child (see also Sackmann, 1999; Kreyenfeld, 2001). They are on average more highly educated and have a much higher full-time employment rate. While 34 percent of East German mothers are employed full-time, only 10 percent in the West are.

[Table 2 about here]

As said above, in the Federal Republic of Germany there are basically no transfer payments that favor cohabiting unions. However, some transfers might set incentives towards single parenthood, especially for women who face poor labor market prospects. The descriptive statistics show that single parenthood is more common among women who neither have a college nor a vocational training degree -- which, in principle, favors this hypothesis. Unfortunately, we do not know anything about the "partnership status" of single parents --i.e. if they are single parents because they split up with their partner, or whether they simply did not move in with a partner. Since we are not able to

7 Otherwise, it would have been more appropriate to employ event history techniques on the transition to the first marriage (see e.g. Andersson, 1999).

8 Moreover, we omitted respondents with missing information on educational attainment (for details, see Table A1 in the Appendix). 
incorporate the partnership status and the disruption risk into the analysis, we will omit single parents from the subsequent analysis and concentrate on women with children (ages 3-6) who are living in marital and cohabiting unions at the date of interview.

In a logistic regression model, we estimate the probability of living in a marital versus a cohabiting union. Our key focus of interest is the extent to which women's employment relates to marital status. We distinguish among women who are employed full-time, part-time and not at all. Since marriage is an institution that supports the nonemployment of one partner, we should find a negative correlation between women's employment and living in a marital union. ${ }^{9}$ Apart from women's employment, we use, in line with other studies, educational attainment as an indicator for women's work orientation. This variable also reflects general labor market advantages, which, particularly in the East German case, are strongly correlated with educational attainment (Brinkmann and Wiedemann, 1995: 330; Mayer et al., 1999). We distinguish between "no degree," "vocational degree," "college degree," and "in education" at the date of interview. Furthermore, we add the employment status and the educational attainment of the partner. As said before, marriage is particularly beneficial if couples follow a gender-specific division of labor --i.e. the "single earner/ male bread-winner model." Against this background, women with partners who are unable to fulfill the role of a "family provider" (e.g. because of unemployment) should have a lower incentive to get married. Apart from the woman and her partner's employment characteristics, we add the woman's current age and an indicator variable for having a second child to the regression.

Table 3 displays the results from the estimations. For West German women, we find the expected pattern of a strong, highly significant and negative correlation between employment and marriage. Women who are not employed or working part-time are

9 This implies that couples anticipate the woman's future employment behavior when they decide to get married. We are, however, unable to sort out the temporal order of the withdrawal from the labor market, the birth of the first child and the marriage decision. However, even if we had this information, it is unlikely that it would provide a deeper insight into the causal mechanisms working behind the decisions to get married. Although the decision to get married might be motivated by the intention to become a housewife and mother, a large number of women are still childless and in full-time employment at the time they get married. 
substantially more likely to be married than full-time employed women. For East Germans, however, we do not find such a clear pattern. Similar to the West, part-time employed women are more likely to be married than full-time employed women. However, women who are not employed are just as likely to be married as women working full-time.

How can we interpret this finding? As already noted above, it is important to take into consideration that East and West German women with children differ in their general orientation towards employment. While the overwhelming majority of non-working West German mothers ( 88 percent) report that they do not intend to return to the labor market, in the East German sample the large majority (65 percent) is either actively looking for employment or at least intending to return to employment in the near future. From this data, we conclude that in East Germany non-working women do not in general consider themselves homemakers and, even when out of work, are still "work oriented." Regarding the role of women's educational attainment in marriage, we find a positive impact of having a college degree on the probability of getting married. These findings oppose our expectation that more work-oriented women would be less likely to get married. The results from the role of partner's employment provide similar equivocal results. In line with our expectations, there is a strong negative effect of having an unemployed partner on being married. However, we do not find any correlation between the partner's educational attainment and marriage.

[Table 3 about here]

We have argued above, that in Germany, the more unequal the labor market position of the woman and her partner, the higher the relative gains of marriage. From this it follows that not the absolute but rather the relative labor market situation between the woman and her partner should have a bearing on marriage decisions. In the following, we address this issue by "combining" the woman and her partner's educational attainment. We do not use the employment status at the date of interview, since educational attainment presumably better reflects long-term employment chances. Table 
4 comprises the various combinations of the educational attainment of the woman and her partner. It is worth noting that in East Germany, assortative mating is more common than in the West. About 83 percent of East German mothers live with a partner who has the same educational level while in the West, 72 percent do. This pattern partially reflects a higher educational attainment among East German women (for details, see Wirth, 2000).

[Table 4 about here]

Table 5 contains the results of a logistic regression model on the probability of getting married versus cohabiting with the various combinations of the woman and her partner's educational attainment as independent variables. Again, the results for West Germany fit our expectations quiet well. Women who are better educated than their partners are less likely to be married (compared to couples where both partners have a vocational degree). However, the results for East Germany do not fit our hypothesis at all. Women with higher educated partners have the same marriage risks as couples where both have a vocational degree. Even more surprisingly, women who are better educated than their partners have the highest marriage risks (compared to all other categories). Although studies from other countries such as the U.S. and Sweden report similar findings (e.g. Oppenheimer, 1995; Duvander 1999), this effect is still puzzling in the German institutional context, since it would suggest that East German women have gained the role of family provider.

[Table 5 about here] 


\section{East-West Comparison}

The results thus far indicate that employment and educational attainment operate differently in East and West. However, by estimating two separate models for the two parts of the country, we cannot tell whether the differences are statistically significant. Although we know that in the East highly educated women display higher marriage risks than other women (particularly when they have a less educated partner), we cannot say for sure if highly educated East German women are more likely to be married than their West German counterparts. In order to test whether the differences are statistically significant, we pool East and West Germans into one sample and estimate a single regression. We allow, however, the covariates to vary flexibly for East and West. In the first step, we estimate several models focusing on women's absolute educational attainment (Model 1a-1c), and in the second step on women's educational attainment relative to the one of their partners (Model 2a-2e).

Table 6 displays the results from the various models, which show that for almost all subcategories West German women are more likely to be married. The only exceptions are women who have a higher educational attainment than their partner. For this subcategory, East and West Germans do not differ significantly. This result sheds new light on our previous findings. While so far we would have argued that college educated East German women (particularly when they are living with a partner with a lower educational attainment) are more likely to get married, we now have to assess that this is only true compared to East German women who hold less than a college degree. Compared to their West German counterparts, they are, however, substantially less likely to be married.

[Table 6 about here] 


\section{Conclusion}

In this paper, we investigated the role of women's employment in non-marital childbearing in East and West Germany during the 1990s. We began our discussion by sketching the development in former East and West Germany. While researchers established the pattern of a "child oriented" marriage in the West, in the East nonmarital birth rates had steadily increased since the 1970s. This development has frequently been related to peculiarities of GDR-family policies, which offered more favorable parental leave regulations to single mothers. Although these measures were primarily designed to facilitate the living conditions of single mothers, they simultaneously set an incentive for couples not to get married upon childbirth. In the late 1980s, the GDR government finally extended parental leave to all mothers, irrespective of family status. The amendment of this regulation put a halt to the steady increase in non-marital birth rates, but the rates did not decline until the breakdown of the GDR. With the unification of the two Germanies and the replacement of East German institutions with West German ones, the general expectation was that nonmarital birth rates would soon fall to West German levels. However, in the 1990s they continued to increase even further, exceeding 50 percent in 2000.

Given that the increase in non-marital birth rates during GDR-times was largely triggered by special treatment for single mothers, it seems obvious to relate the continuous increase in non-marital childbearing after unification to similar "misguided" family policies. However, non-marital birth rates remained at a low level in the western parts of the country where women were subject to the same legal and political constraints. One obvious hypothesis to resolve this puzzle is to assume that East German women are strategically using the new incentive structure, while West German have, for one reason or the other, "failed" to take advantage of them.

A closer examination of FRG-family policies in fact reveals that there are various regulations, which are designed to improve the living conditions of single parents. For example, single parents have priority access to children's day care, welfare benefits and housing subsidies. Although such regulations can set incentives to remain unmarried upon childbirth, we argued that this does not fully apply to the regulations in the Federal Republic of Germany. Most importantly, "non-marital childbearing" unifies a bundle of 
heterogeneous family forms such as single parenthood and parenthood in cohabiting unions. This distinction is not only essential from an analytical point of view, but FRGfamily policies make an explicit distinction among single parents, cohabiting and married couples. While single parents get priority access to certain social transfers, cohabiting and married couples are treated alike in most cases --i.e. the partner's income is assessed when the couple claims social benefits. This means that while some incentives might keep couples from moving together, there are no transfer payments which discourage cohabiting couples from getting married. Since the majority of unmarried East German mothers are living in cohabiting unions, special treatments to single parents are unlikely to explain the increase in non-marital birth rates in East Germany of the 1990s.

Against this background, one of the crucial questions is why East German couples in cohabiting unions are more reluctant to get married upon childbirth than their West German counterparts. The main hypothesis, we set up in this context, evolves around women's employment behavior. The German tax and transfer system --i.e. the system of income splitting, the coverage of the non-working spouse in the national health insurance and the widow's pension-- is particularly beneficial for married couples who follow the gender specific division of labor. In other words, this system sets strong incentives to get married --given that one of the partners strongly reduces his or her workload after childbirth. One of the most glaring differences between the eastern and western parts of Germany in the 1990s are, however, differences in the employment patterns of mothers. While West German women either give up their career, reduce their working hours or interrupt their employment for a longer time period after childbirth, East German women show a completely different pattern. They return to full-time employment more quickly after childbirth, those who are not employed express a greater desire to return to full-time employment, and those working part-time more often want to extend their working hours.

The reasons for high female employment rates in the East are manifold, though. The one most often mentioned is the high work orientation which East German women kept as a holdover from GDR-times. Presumably as important are the institutional constraints. On the one hand, the unfavorable male employment situation might put East German women under greater financial pressure to be employed. On the other hand, they 
experience better opportunities to combine childrearing and employment, due to a greater abundance of children's day care. Whatever the more apt explanation is, we supposed that a higher work orientation and more favorable constraints to combine childrearing and employment has an important bearing on marriage decisions upon childbirth. Given that in Germany marriage is particularly beneficial for couples who follow the traditional division of labor, our main hypothesis was that East-West differences in non-marital childbearing primarily relate to difference in women's employment patterns.

In order to test this hypothesis we estimated several logistic regression models on the probability of living in a marital versus cohabiting union (at the date of interview for women with children age 3-6). As an indicator for a woman's work orientation, we used employment status and educational attainment. Furthermore, we controlled for the partner's characteristics and investigated the role of educational homogamy for the probability to live in a marital versus cohabiting union. The logic behind this is that the benefits to marriage are greater the more unequal the partners' labor market status. Hence, given that education is a valid indicator for long-term employment chances, we expected that heterogam couples have the highest incentive to get married.

For West Germany, we found the expected pattern. Here, a relatively high female work orientation is indeed negatively correlated with being married. For East Germany, however, we did not find such a pattern. Here, the employment status is hardly correlated with the marital status. Furthermore, East German women with a college degree appeared to be more likely to get married than the less educated, and women with a relatively higher educational level than their partners were significantly more likely to be married than any other reference category. However, East German women with a college degree had a relatively higher marriage risk only when compared to East German women who hold less than a college degree. Compared to their West German counterparts, they were less likely to be married. In addition to that, basically all educational categories in East Germany displayed significantly lower marriage risks than in West Germany.

Against the background of our empirical findings, one might claim that we have to reject our main hypothesis, since we cannot break down the East-West differences in non-marital childbearing by variables which are commonly used to indicate women's 
work orientation. However, there are both methodological as well as theoretical arguments that may explain the observed patterns. One possible explanation is that standard variables such as educational attainment do not sufficiently indicate East German women's work orientation. In a similar manner, women's employment status measured at the date of interview may not validly represent women's long-term employment plans. Besides considerations like these, it is of major importance to take into account the different constraints for combining childrearing and employment in both parts of the country. The much greater abundance of public day care in the eastern states allows the overwhelming majority of women to take mothers' full-time employment for granted. In other words, in East Germany pursuing an employment career is not a "privilege" for highly educated mothers. Women's full-time employment is generally considered as a matter of course and women who are out of work are expected to return to full-time employment. A wide availability of public day care and high female work orientation, in turn, strongly reduce the economic incentives for women to get married upon childbirth. Against this background, it is comprehensible why marriage, as an institution for raising children, is less prevalent in East than in West Germany. 
Acknowledgments: For valuable comments we would like to thank Johannes Huinink, Heike Trappe and the participants of the conference on "the 2nd demographic transition in Europe" which was held in Bad Herrenalb in June 2001. We would also like to thank two anonymous reviewers of Population for their constructive comments and suggestions on an earlier version of this paper. For editing, we are grateful to Sheila Mulrooney Eldred and Susann Backer. 


\section{References}

ADLER M.A., 1997, "Social change and decline in marriage and fertility in Eastern Germany", Journal of Marriage and the Family 59(1), pp. 37-49.

ANDERSSON, G., 1998, "Trends in marriage formation in Sweden 1971-1993", European Journal of Population 14(4), pp. 157-178.

BECKMANN P., ENGELBRECH G., 1999, "Beschäftigungsentwicklung und Perspektiven ostdeutscher Frauen in den 90er Jahren", in E. Wiedemann (et al.) (eds.), Die arbeitsmarkt- und beschäftigungspolitische Herausforderung in Ostdeutschland, Nürnberg, Bundesanstalt für Arbeit, pp. 203-226.

Bennett N.G., Blanc A.K., Bloom D.E., 1988, "Commitment and the modern union: assessing the link between premarital cohabitation and subsequent marital stability", American Sociological Review 53(1), pp. 127-138.

BerghaHn S., 1992, "Frauenrechte im Vereinigungsprozeß. Das Ende der Privilegien oder sozialer Kahlschlag?", in C. Faber, T. Meyer (eds.), Unterm neuen Kleid der Freiheit: Das Korsett der Einheit. Auswirkungen der deutschen Vereinigung für Frauen in Ost- und Westdeutschland, Berlin, Ed. Sigma, pp. 63-98.

Braun M., ScotT J., ALWIN D.F., 1994, "Economic necessity or self-actualization? Attitudes toward women's labour-force participation in East and West Germany", European Sociological Review 10(1), pp. 29-47.

BRINKMANN C., WIEDEMANN E., 1995, "Arbeitsmarktrisiken im ostdeutschen Transformationsprozess: Ergebnisse des Arbeitsmarkt-Monitors 1989 bis 1994", Mitteilungen aus der Arbeitsmarkt- und Berufsforschung 28(3), pp. 323-338.

BUNDESMINISTERIUM FÜR ARBEIT UND SOZIALORDNUNG (BMA), 2000, "Übersicht über das Sozialrecht”, 6th revised and enlarged edition, Bonn.

Council of Europe, 2000, "Recent Demographic Developments in Europe", Strasbourg.

Cromm J., 1998, "Familienbildung in Deutschland: soziodemographische Prozesse, Theorie, Recht und Politik unter besonderer Berücksichtigung der DDR", Opladen, Westdeutscher Verlag.

DEUTSCHES JUGENDINSTITUT, 1993, "Tageseinrichtungen für Kinder. Informationen, Erfahrungen, Analysen”, München: Deutsches Jugendinstitut.

DeuTSCHES JUGENDINSTITUT, 1998, “Tageseinrichtungen für Kinder. Pluralisierung von Angeboten", München: Deutsches Jugendinstitut.

DORBRITZ J., 1997, "Der demographische Wandel in Ostdeutschland - Verläufe und Erklärungsansätze”, Zeitschrift für Bevölkerungswissenschaft 22(2-3), pp. 239-268.

DORBRITZ J., 2000, "Europäische Fertilitätsmuster", Zeitschrift für Bevölkerungswissenschaft 25(2), pp. 235-266.

DROBNIČ S., 2000, "The effects of children on married and lone mother's employment in the United States and (West) Germany", European Sociological Review 16(2), pp. 
$137-157$.

DUVANDER A.Z.E., 1999, "The transition from cohabitation to marriage: a longitudinal study of the propensity to marry in Sweden in the early 1990s", Journal of Family Issues 20(5), pp. 698-717.

EMMERLING D., RIEDE T., 1997, "Vierzig Jahre Mikrozensus”, Wirtschaft und Statistik (3), pp. 160-174.

ENGELBRECH G., 1997, "Erziehungsurlaub - und was dann? Die Situation von Frauen bei ihrer Rückkehr auf den Arbeitsmarkt: ein Ost/ West-Vergleich", IAB Kurzbericht (8).

Frerich J., FREY M., 1993, "Handbuch der Geschichte der Sozialpolitik in Deutschland, Band 2: Sozialpolitik in der Deutschen Demokratischen Republik", München, Oldenbourg Verlag.

Frerich J., FREY M., 1996, "Handbuch der Geschichte der Sozialpolitik in Deutschland. Band 3: Sozialpolitik in Deutschland bis zur Herstellung der deutschen Einheit", 2.nd edition, München, Oldenbourg Verlag.

GYSI J., SPEIGNER W., 1983, "Changes in the life patterns of families in the German Democratic Republic", Berlin (East): Institut für Soziologie und Sozialpolitik an der Akademie der Wissenschaft der Deutschen Demokratischen Republik.

HÖHN C., 1992, "Population-relevant policies before and after unification of Germany", in P. Krishnan, C.H. Tuan, K. Mahadevan (eds.): Readings in Population Research, Dehli (India), pp. 1-24.

HÖHN C., DORBRITZ J., 1995, "Zwischen Individualisierung und Institutionalisierung Familiendemographische Trends im vereinten Deutschland", in B. Nauck, C. OnnenIsemann (eds.), Familie im Brennpunkt von Wissenschaft und Forschung, Neuwied, Luchterhand: pp. 149-176.

Holst E., SCHUPP J., 1999, "Erwerbsbeteiligung und Arbeitszeitwünsche 1993 und 1997. West- und Ostdeutschland im Vergleich", in W. Glatzer, I. Ostner (eds.), Deutschland im Wandel: sozialstrukturelle Analysen. Opladen, Leske und Budrich, pp. 289-306.

HUININK J., 1998, "Ledige Elternschaft junger Frauen und Männer in Ost und West”, in R. Metze (et al.) (eds.), Der Transformationsprozess: Analysen und Befunde aus dem Leipziger Institut für Soziologie. Leipzig, Leipziger Universitätsverlag: pp. 301-320.

HUININK J., 1999, "Die Entscheidung zur Nichtehelichen Lebensgemeinschaft als Lebensform - Ein Vergleich zwischen Ost- und Westdeutschland", in T. Klein, W. Lauterbach, (eds.), Nichteheliche Lebensgemeinschaften. Analysen zum Wandel partnerschaftlicher Lebensformen, Opladen, Leske und Budrich: pp. 113-138.

Huinink J., Wagner M., 1995, "Partnerschaft, Ehe und Familie in der DDR", in J. Huinink (et al.) (eds.), Kollektiv und Eigensinn. Lebensverläufe in der DDR und danach. Berlin, Akademie Verlag: pp. 145-188.

Huinink, J., KonietzKA, D., 2002, "Lebensformen und Familiengründung. Nichteheliche Elternschaft in Ost- und Westdeutschland in den 1990er Jahren", University of Rostock, mimeo.

KReYenfeld M., HuininK J., 2002, "Der Übergang zum ersten und zweiten Kind. Ein Vergleich zwischen Mikrozensus und Familiensurvey", Rostock University, mimeo. 
KREYeNFELD M., 2001, "Employment and Fertility - East Germany in the 1990s", University of Rostock. Ph.D. Thesis.

MaYer K.U., Diewald M., Solga H., 1999, "Transitions to post-communism in East Germany: Worklife mobility of woman and men between 1989 and 1993", Acta Sociologica 42(1): pp. 35-53.

NAVE-HERZ R., 1994, "Familie heute", Darmstadt: Wissenschaftliche Buchgesellschaft.

OBERTREIS G., 1986, “Familienpolitik in der DDR 1946-1980“, Opladen, Leske und Budrich.

OPPENHEIMER V.K., 1995, “The role of women's economic independence in marriage formation", in H.P. Blossfeld (ed.), The New Role of Women. Boulder, Westview Press: pp. 236-243.

PEUCKERT R., 1999, “Familienformen im sozialen Wandel”, 3rd edition. Opladen: Leske und Budrich.

RALEY K.R., 2001, "Increasing fertility in cohabiting unions. Evidence for the second demographic transition in the United States?", Demography 38(1): pp. 59-66.

RindFuss R.R., BREwSTER K.L., 1996, "Childrearing and fertility", Population and Development Review 22(Supplement): 258-289

SACKMANN R., 1999, "Ist ein Ende der Fertilitätskrise in Ostdeutschland absehbar?", Zeitschrift für Bevölkerungswissenschaft 24(2): pp. 187-211.

SAINSBURY D., 1997, "Taxation, family responsibilities, and employment", in D. Sainsbury (ed.), Gender and Welfare State Regimes, Oxford, Oxford University Press, pp. 185-209.

SCHIMPL-NEIMANNS B., 1998, "Analysemöglichkeiten des Mikrozensus", ZUMANachrichten 22(42): pp. 91-122.

SCHNEIDER N.F., MATTHIAS-BLECK H. (1999): "Moderne Familie - altes Recht?", in F.W. Busch (et al.) (eds.), Aktuelle Forschungsfelder der Familienwissenschaft, Würzburg, Ergon Verlag, pp. 185-210.

SEltzer J., 2000, "Families formed outside of marriage", Journal of Marriage and the Family 62(4): pp. 1247-1268.

Smock P.J., 2000, "Cohabiting in the United States. An appraisal of research themes, findings, and implications", Annual Review of Sociology 26: pp. 1-20.

StATISTISCHES BundeSAMt, 2001a, "Bevölkerung und Erwerbstätigkeit. Gebiet und Bevölkerung 1999.” Fachserie 1, Reihe 1. Stuttgart: Metzler-Poeschel.

STATISTISCHES BUNDESAMT, 2001b, "Altersspezifische Geburtenziffern für Ost- und Westdeutschland für das Jahr 2000", provided as a personal correspondence to Dieter Emmerling (Statistisches Bundesamt).

STATISTISCHES BundeSAMT, 2001c, "Sozialleistungen. Tageseinrichtungen für Kinder 1998”, Stuttgart.

TrAPPE H., 1995, “Emanzipation oder Zwang? Frauen in der DDR zwischen Beruf, Familie und Sozialpolitik”, Berlin, Akademie Verlag.

WIRTH H. (2000), "Bildung, Klassenlage und Partnerwahl”, Opladen, Leske und 
Budrich.

WitTE J.C., WAGNER G.G., 1995, "Declining fertility in East Germany after unification: a demographic response to socioeconomic change", Population and Development Review 21(2): pp. 387-397. 


\section{Tables}

TABle 1.- Provision of Public Day CARE 1990, 1994, 1998

\begin{tabular}{|l|r|r|r|r|r|r|}
\hline & \multicolumn{3}{|c|}{ West Germany } & \multicolumn{3}{c|}{ East Germany } \\
& 1990 & 1994 & 1998 & 1990 & 1994 & 1998 \\
\hline Provision Rate & & & & & & \\
Age 0-3 (Krippe) & $2 \%$ & $2 \%$ & $3 \%$ & $56 \%$ & $41 \%$ & $36 \%$ \\
Age 4-6 (Kindergarten) & $78 \%$ & $85 \%$ & $102 \%$ & $113 \%$ & $117 \%$ & $132 \%$ \\
Age 7-10 (Hort) & $5 \%$ & $5 \%$ & $6 \%$ & $88 \%$ & $58 \%$ & $48 \%$ \\
Kindergarten (full-time) & n.a. & $14 \%$ & $19 \%$ & n.a. & $113 \%$ & $129 \%$ \\
& & & & & & \\
Day care Slots (in 1,000) & 38 & 47 & 58 & 353 & 103 & 109 \\
Age 0-3 (Krippe) & 1,552 & 1,918 & 2,151 & 888 & 552 & 335 \\
Age 4-6 (Kindergarten) & 128 & 145 & 179 & 818 & 485 & 271 \\
Age 7-10 (Hort) & n.a. & 324 & 405 & n.a. & 535 & 327 \\
Kindergarten (full-time) & & & & & & \\
& & & & & \\
Number of Children (in 1,000) & 2,144 & 2,143 & 2,095 & 626 & 250 & 298 \\
Age 0 to 3 & 1,981 & 2,251 & 2,110 & 785 & 473 & 253 \\
Age 4 to 6 & 2,565 & 2,846 & 3,027 & 930 & 833 & 569 \\
Age 7 to 10 & & & \\
\hline Notes: (1) Provision Rate: available slots per 100 children of an age group (2) n.a.=not available \\
Source: Deutsches Jugendinstitut (1993, 1998); Statistisches Bundesamt (2001a,c)
\end{tabular}


TABle 2.- Descriptive Statistics (In PERCENT), Population: WoMen of THE

COHORTS 1961-1980 WITH A CHILD AGE 3-6, Year OF SURVEY: 1997

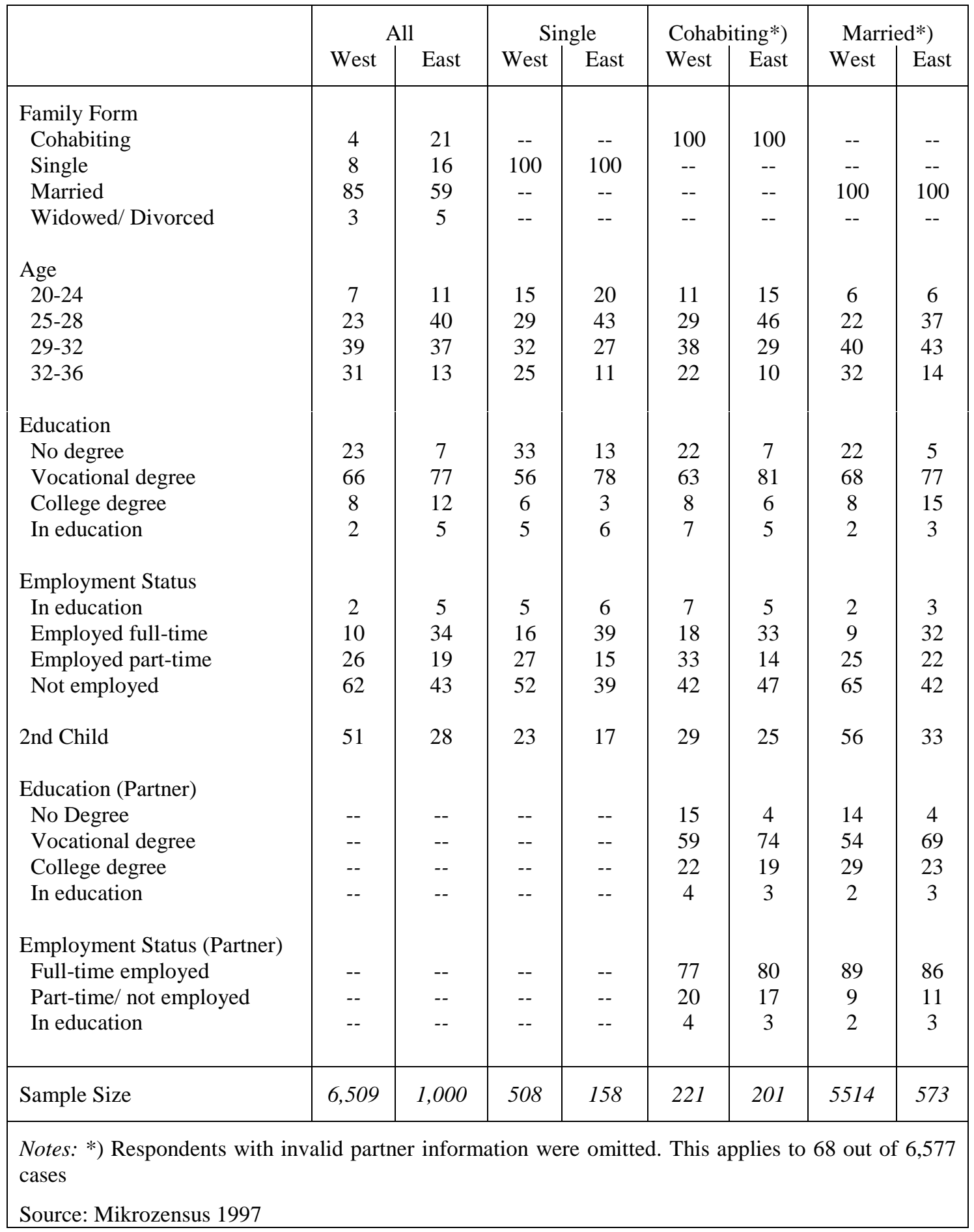


TABLE 3.- LOGISTIC REGRESSION MODEL,

DEPENDENT VARIABLE: "MARITAL UniON" VERSUS “COHABITING UniON"

\begin{tabular}{|c|c|c|c|c|c|c|}
\hline & & West Ge & $\operatorname{mans}$ & & East Ge & mans \\
\hline & $\mathrm{b}$ & $\exp (b)$ & $\mathrm{t}$ & $\mathrm{b}$ & $\exp (b)$ & $\mathrm{t}$ \\
\hline Intercept & 3.25 & 25.78 & $19.11 * * *$ & 1.12 & 3.06 & $5.32 * * *$ \\
\hline Age & & & & & & \\
\hline $20-24$ & -0.57 & 0.57 & $-2.19 * *$ & -1.14 & 0.32 & $-3.69 * * *$ \\
\hline $25-28$ & -0.29 & 0.74 & $-1.67 *$ & -0.52 & 0.59 & $-2.60 * * *$ \\
\hline $29-32$ & 0 & 1 & & 0 & 1 & \\
\hline $32-36$ & 0.39 & 1.48 & $2.09 * *$ & -0.09 & 0.92 & -0.30 \\
\hline Education & & & & & & \\
\hline In Education & -1.46 & 0.23 & $-4.58 * * *$ & -0.31 & 0.73 & -0.72 \\
\hline No degree & 0.06 & 1.07 & 0.33 & -0.23 & 0.79 & -0.58 \\
\hline Vocational degree & 0 & 1 & & 0 & 1 & \\
\hline College degree & -0.05 & 0.95 & -0.18 & 0.59 & 1.80 & $1.66 *$ \\
\hline Employment & & & & & & \\
\hline Employed full-time & -0.88 & 0.41 & $-4.28 * * *$ & 0.04 & 1.04 & 0.19 \\
\hline Employed part-time & -0.53 & 0.59 & $-3.10 * * *$ & 0.58 & 1.78 & $2.25 * *$ \\
\hline Not employed & 0 & 1 & & 0 & 1 & \\
\hline 2nd child & 0.89 & 2.43 & $5.60 * * *$ & 0.57 & 1.76 & $2.78 * * *$ \\
\hline Education (Partner) & & & & & & \\
\hline In education & -0.23 & 0.79 & -0.60 & 0.11 & 1.11 & 0.21 \\
\hline No Degree & 0.10 & 1.10 & 0.43 & 0.71 & 2.04 & 1.48 \\
\hline Vocational Degree & 0 & 1 & & 0 & 1 & \\
\hline College Degree & -0.14 & 0.87 & -0.63 & 0.01 & 1.01 & 0.02 \\
\hline Employment (Partner) & & & & & & \\
\hline Part-time/ not employed & -0.63 & 0.53 & $-2.91 * * *$ & -0.56 & 0.57 & $-2.17 * * *$ \\
\hline Employed full-time & 0 & 1 & & 0 & 1 & \\
\hline $\begin{array}{l}\text { Notes: Selection of the sa } \\
\text { age 3-6 }\end{array}$ & narried & and coha & iting wome & cohort & ts $1961-1$ & 80 with a cl \\
\hline Source: Mikrozensus 199 & & & & & & \\
\hline
\end{tabular}


TABLE 4.- EDUCATIONAL HOMOGAMY (IN PERCENT)

\begin{tabular}{|l|c|c|}
\hline & West Germans & East Germans \\
\hline Both no degree & $10 \%$ & $2 \%$ \\
Both vocational degree & $56 \%$ & $74 \%$ \\
Both college degree & $6 \%$ & $7 \%$ \\
Women's education > Partner's education & $7 \%$ & $7 \%$ \\
Women's education < Partner's education & $22 \%$ & $9 \%$ \\
\hline Sample Size & 5,503 & 727 \\
\hline
\end{tabular}

Notes: Selection of the sample: married and cohabiting women of the cohorts 1961-1980 with a child age 3-6. Women in education or with partner in education were omitted.

Source: Mikrozensus 1997 
Table 5.- Logistic Regression Model, Dependent Variable: "Marital Union" VERSUS “COHABITING UNION”; FOCUS OF MODEL: EDUCATIONAL HOMOGAMY

\begin{tabular}{|c|c|c|c|c|c|c|}
\hline & \multicolumn{3}{|c|}{$\begin{array}{l}\text { West Germans } \\
\exp (b) \quad t\end{array}$} & \multicolumn{3}{|c|}{ East Germans } \\
\hline Intercept & 2.89 & 17.99 & $20.96 * * *$ & 1.26 & 3.53 & $7.52 * * *$ \\
\hline \multicolumn{7}{|l|}{ Age } \\
\hline $20-24$ & -0.50 & 0.61 & $-1.90 *$ & -1.32 & 0.27 & $-4.29 * * *$ \\
\hline $25-28$ & -0.17 & 0.84 & -0.91 & -0.56 & 0.57 & $-2.77 * * *$ \\
\hline $29-32$ & 0 & 1 & & 0 & 1 & \\
\hline $32-36$ & 0.3 & 1.35 & 1.62 & -0.19 & 0.83 & -0.62 \\
\hline 2nd child & 1.07 & 2.92 & $6.86 * * *$ & 0.40 & 1.49 & $2.01 * *$ \\
\hline \multicolumn{7}{|l|}{ Education } \\
\hline Both no degree & 0.30 & 1.35 & 1.07 & 0.21 & 1.23 & 0.37 \\
\hline Both vocational degree & 0 & 1 & & 0 & 1 & \\
\hline Both college degree & 0.16 & 1.17 & 0.41 & 0.51 & 1.67 & 1.27 \\
\hline Women's education > Partner's education & -0.63 & 0.53 & $-2.66 * * *$ & 1.08 & 2.94 & $2.21 * *$ \\
\hline Women's education < Partner's education & -0.29 & 0.75 & $-1.65 *$ & 0.00 & 1.00 & 0.01 \\
\hline
\end{tabular}




\section{TABle 6.- Results From VARIOUS LOGISTIC REGRESSION MODELS With CHANGing REFERENCE CATEGORIES}

\begin{tabular}{|c|c|c|c|c|c|c|}
\hline & & \multicolumn{3}{|c|}{ West } & \multicolumn{2}{|c|}{ East } \\
\hline & & $\mathrm{b}$ & $\exp (b)$ & $\mathrm{t}$ & $\mathrm{b}$ & $\exp (b)$ \\
\hline \multicolumn{7}{|c|}{ Absolute Educational Attainment } \\
\hline Model 1a & Both no degree & 2.40 & 10.99 & $6.66 * * *$ & 0 & 1 \\
\hline Model 1b & Both vocational degree & 1.99 & 7.32 & $14.86 * * *$ & 0 & 1 \\
\hline Model 1c & Both college degree & 1.01 & 2.73 & $2.44 * * *$ & 0 & 1 \\
\hline \multicolumn{7}{|c|}{ Relative Educational Attainment } \\
\hline Model 2a & Both no degree & 2.39 & 10.92 & $4.02 * * *$ & 0 & 1 \\
\hline Model 2b & Both vocational degree & 2.11 & 8.23 & $14.51 * * *$ & 0 & 1 \\
\hline Model 2c & Both college degree & 1.76 & 5.79 & $3.21 * * *$ & 0 & 1 \\
\hline Model 2d & Women's education > Partner's education & 0.38 & 1.46 & 0.72 & 0 & 1 \\
\hline Model 2e & Women's education $<$ Partner's education & 1.95 & 7.05 & $6.29 * * *$ & 0 & 1 \\
\hline
\end{tabular}




\section{Figures}



Figure 1. - Non-marital Births in East and West Germany (as percentage of all births) Notes: Data from the year 2000 are preliminary estimates provided by the Statistisches Bundesamt. Source: Statistisches Bundesamt (2001a; 2001b) 


\section{East Germany}

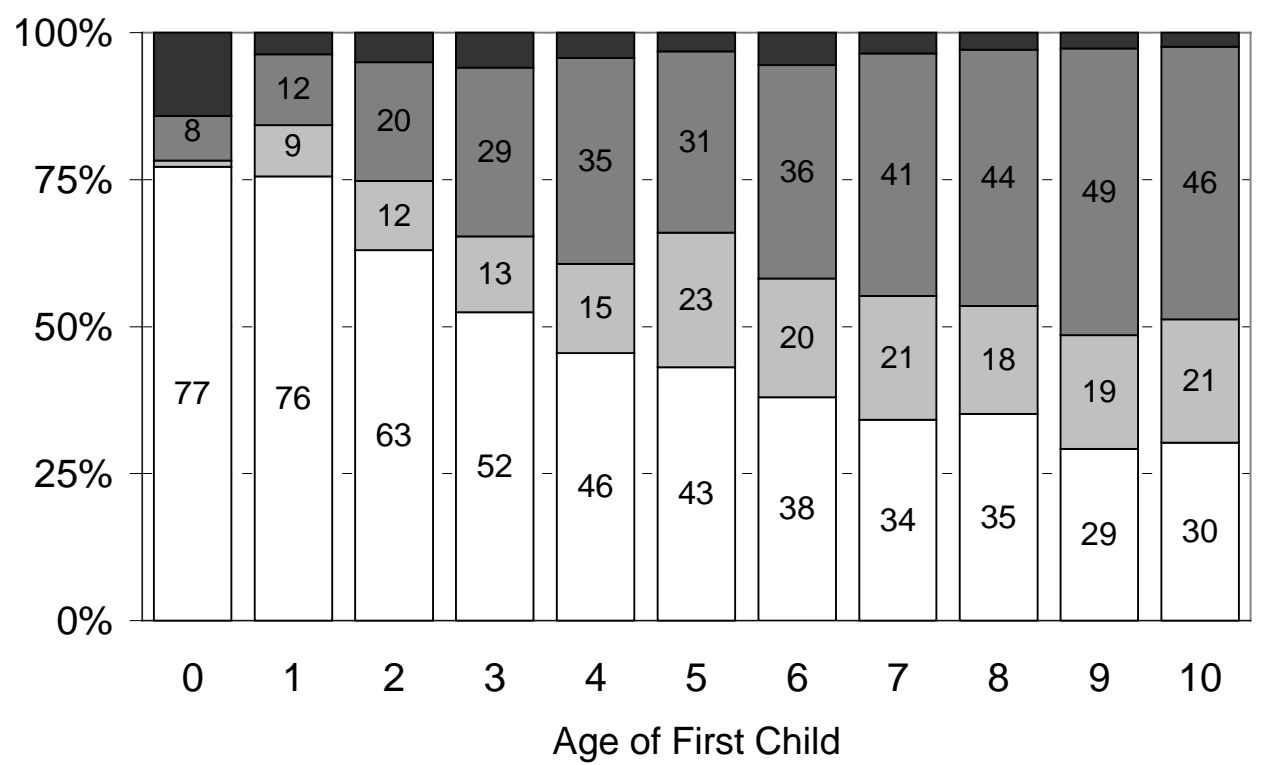

West Germany

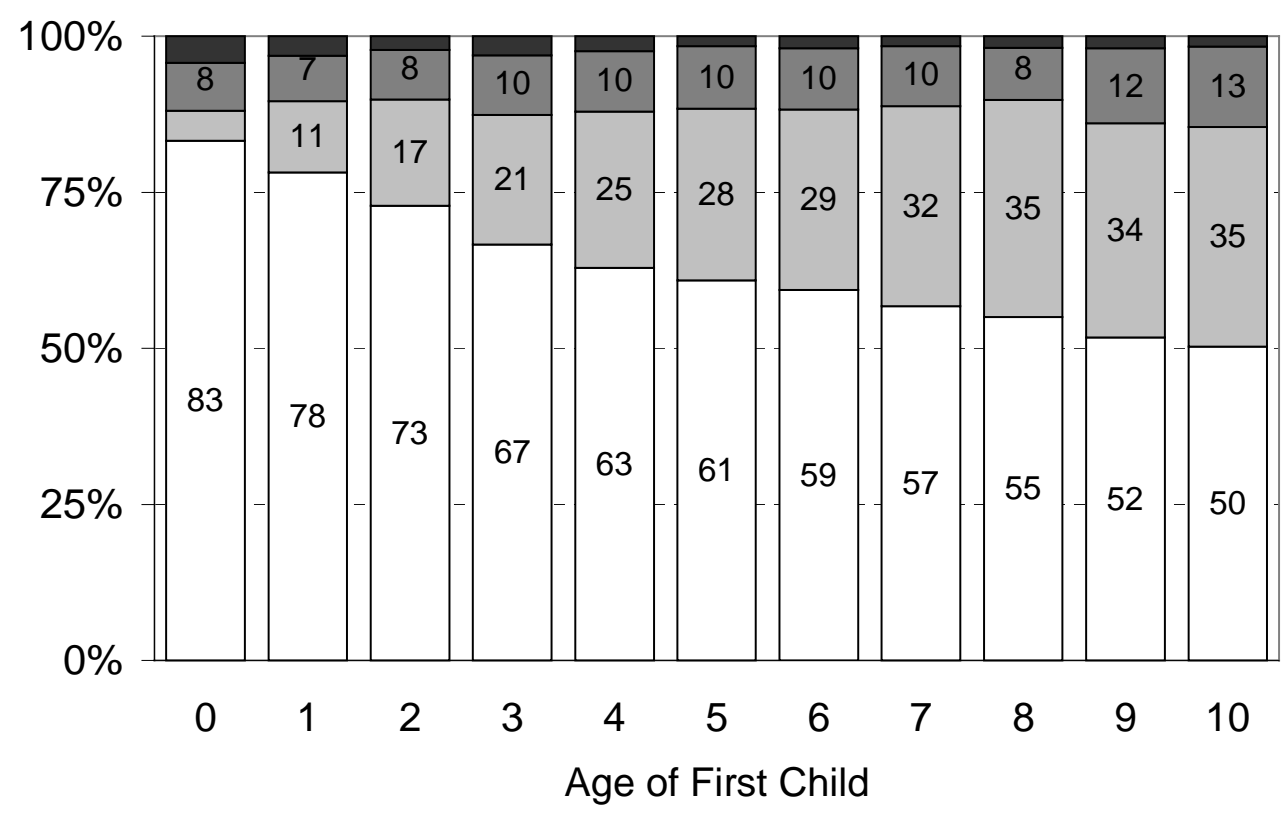

$\square$ Not employed $\square$ Part-time $\quad \square$ Full-time $\quad \square$ In education

Figure 2. - Percentage of Employed Women by Age of First Child in 1997

Notes: (1) Employed full-time, i.e. 35 and more hours per week; employed part-time, i.e. 1-35 hours working hours per week (2) Population: women of the birth cohorts 1961-1980 who had at least one child age $0-10$ at the date of interview in 1997

Source: Mikrozensus 1997 (own estimations) 
(Conditional) Survival Curve to First Marriage by Age of First Child Population: Women of the Cohorts 1961-1980 who had a first child between 1991-1996

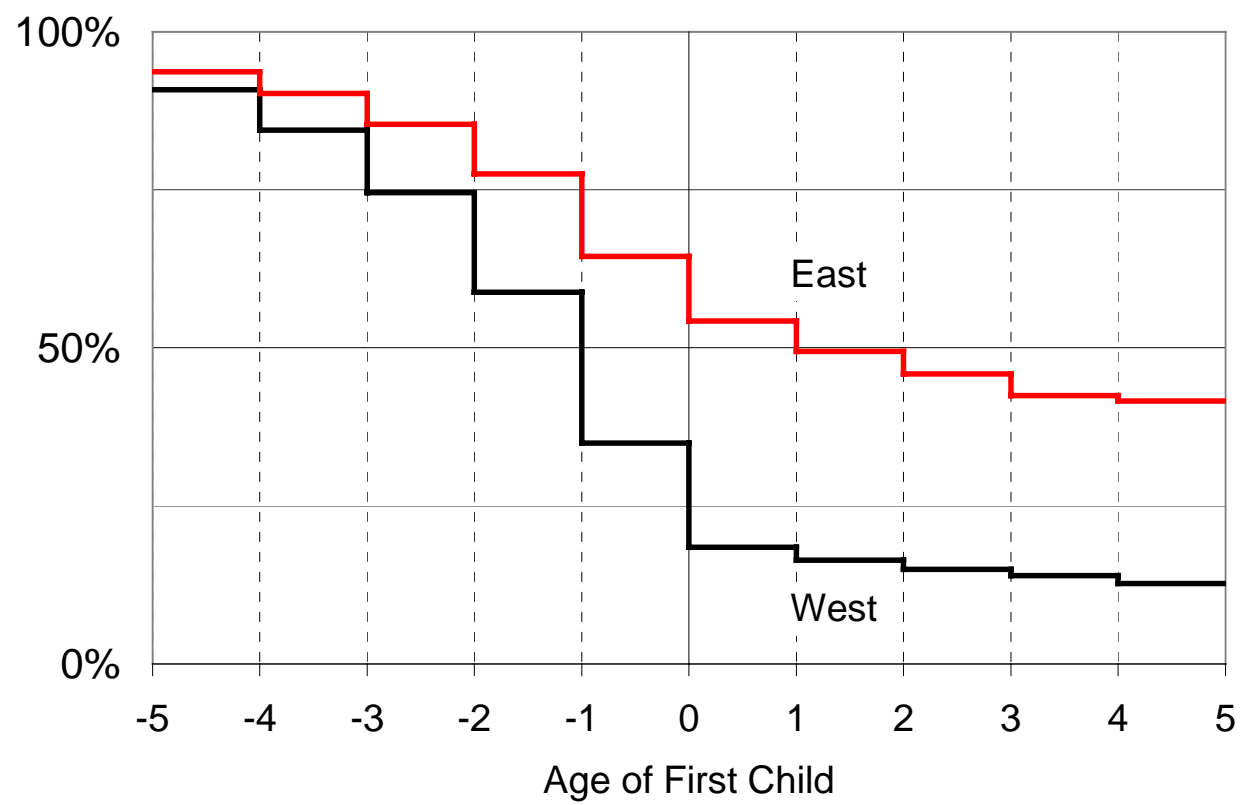

(Conditional) Survival Curve to First Marriage by Age of Second Child Population: Women of the Cohorts 1961-1980 who had a second child between 1991-1996



Figure 3. - Survival Curves, Transition to First Marriage by Age of Child (Percentage still unmarried by age of first and second child)

Source: Mikrozensus 1997 (own estimations) 


\section{Appendix}

\section{Description of the Variables}

\section{Fertility History}

A woman is assumed to have given birth if she is labeled as "head of the family" or "partner of the head of the family" and if she is living in the same family with a person who is labeled as "child in the family." The age and order of the birth is inferred from the age and the number of children in the family, i.e., the difference between the year of birth of the mother and the age of the child.

\section{Family Form}

In the Mikrozensus all household members are surveyed. Apart from marital status, respondents are requested to report their relationship to the "head of the household" (i.e. whether he/she is the "partner"). Based on the marital status and information on the relationship to the "head of the household," we distinguish the following four family forms.

- Married women include all women who report that they are married. This is irrespective of whether they are living with a partner.

- Widowed and divorced women include all widowed and divorced women irrespective of whether they are living with a partner.

- Cohabiting women refers to all unmarried women who are living in a cohabiting union.

- $\quad$ Single women includes all unmarried women who are not living in a cohabiting union. $^{10}$

In Figure 3, we also use information on the year the respondent got married. It is not possible to say if this information relates to a first or higher order marriage. For simplicity, we assume that it relates to first order marriages. In contrast to most other questions in the Mikrozensus, respondents are free to answer this question. Therefore, the non-response rate for this question is relatively high. In our analysis, we have to omit roughly 10 percent due to non-response. For the multivariate analysis, we use information on the family form at the date of interview. There is no non-response option on this question.

10 Possibly, there are some cohabiting women who misreport their family status. As discussed in Part II, transfer payments are means tested and the cohabiting partner's income is assessed as well. Cohabiting women who are receiving social benefits might report being single, fearing that revealing the cohabiting partner would have negative consequences for being eligible for benefits. However, we do not have any information on this issue. 


\section{Educational Attainment}

There are three binary variables that indicate the highest (post-secondary) degree obtained at the time of interview.

- Vocational degree includes Lehrausbildung, Meister, Fachschulabschluß.

- College includes a university or a college degree (Universitäts-) Fachhoschulabschluß).

- $\quad$ No degree includes respondents who did not earn a post-secondary degree, i.e. who did not receive a vocational training certificate or a college degree. This category also includes respondents who received nothing more than training on the job (Anlernausbildung). Furthermore, it can include respondents who earned a primary or secondary school degree (Hauptschulabschluss, Realschulabschluss, Abitur), provided they did not earn a vocational training certificate or a college degree.

\section{Employment Status}

We distinguish

- In education

- Employed part-time ( $>0$ and $<35$ working hours)

- Employed full-time ( $\geq 35$ working hours)

- Not employed

The employment status was constructed on the basis of information on the working hours in the reference week (Berichtswoche). This means that we wrongly classify individuals as "not employed" who are on sick leave or on holidays during this week. However, if one uses the "current employment status," which is also surveyed, one yields unreasonably high female employment rates. This relates to the fact that women on parental leave are classified as employed. In the German micro-census parental leave take-up is unfortunately not surveyed.

\section{Employment Status of Partner}

We distinguish

- In education

- Employed full-time ( $\geq 35$ working hours)

- Not employed or employed part-time ( $>0$ and $<35$ working hours)

\section{East/ West German}

An East German is a respondent who lived in the five new Länder or East Berlin in 1997. A West German is a respondent who lived in the territories of former West Germany in 1997. 


\section{Sample Size}

TABle A1.- SAMPLE SIZE MIKROZENSUS 1997

\begin{tabular}{|l|r|r|}
\hline $\begin{array}{l}\text { All respondents in Scientific Use File of } \\
\text { Mikrozensus }\end{array}$ & & 509,892 \\
\hline Omitted cases & & \\
Respondents in institutions & 11,414 & \\
Men & 240,541 & \\
Cohort $\leq 1960$ & 149,454 & \\
Cohort $>1980$ & 42,232 & \\
First child < age 17 & 428 & \\
\hline Subtotal & & 65,823 \\
\hline Omitted cases & 57,983 & \\
No child age 3-6 & 331 & \\
Educational attainment missing & & 7,509 \\
\hline Total & & \\
\hline
\end{tabular}

